\section{A survey of corporate governance in banking: characteristics of the top 100 world banks}

\section{Rowan Trayler}

Banking worldwide is a high profile industry and plays an important role Banking worldwide is a high profile industry and plays an not only in a country's economy but the world's as we countries and play a key role in society. world's largest banks span many countries and in ensuring the stability and The banking industry has a special function in ensurial system. If one the world's largest integrity of the worldwide financial system. If one of the world's largest banks were to fail the fear of the consequenceride. Banks are different to nonregulators and governments worldwide. Banks are different to nonfinancial corporations due to their

that they hold in the community.

Corporate governance and the role of the directors in banking has never been more important, not only has there been a large number of changes to corporate governance regulations but bank management has to address the issues in the implementation of the Bank for International Settlements (BIS) Basel II capital adequacy accord. This survey of the world's top 100 banks is to determine if there are similarities or differences in their corbanks is to determine if there are simerice measured by performance and risk. porate governance chara-Oxley Act (SOX) came into force as a reaction to In 2002 the Sarbanes-Oxle the high profile corporate failures of Enron, World Com, Parmalat and others. These failures also highlighted executive compensation arrangements that many investors questioned as being excessive. Various countries ments that many investoris imilar corporate governance legisiation to around the world introduced simil their listing rules in terms of corporate SOX and stock exchanges tightened their ar-reaching effect even in countries governance. The changes are having a far-reach

that have not introduced similar requirements.

Today, banks are large complex organizations with operations not only across countries but are offering a number of example with operthan just commercial banking, Citibank is a good examame tew. The ations in stock broking, insurance, funds management, to name a equipped to understand the complex nature of the organization, the countries they operate in and be able to provide the independent oversight required as directors.

\section{PERSPECTIVES AND RECENT RESEARCH}

Recent research shows that good firm performance is linked to good corporate governance. However LeBlanc and Gillies (2003) suggest the evidence is not as strong as many report, this is also supported by Chidambaran et al. (2006) who find no significant performance differences between firms with good or bad governance changes. Gompers et al. (2003) developed a governance index based on 24 firm specific characteristics around shareholder rights and found that high governance index firms had higher firm value and profits. Brown and Caylor (2004) develop a governance index based on 51 governance factors. They also find higher governance scores drive return on equity and profit margins whilst Core et al. (2006) contend that weak governance did not cause problems with stock returns.

FTSE Research and Institutional Shareholder Services (ISS) produced a joint research report in 2005 about their Corporate Governance Index (CGI) where they rated 2200 companies from 24 countries. In their report they identify five governance areas: ownership, compensation, audit, board and equity structure, on which they based their index calculations. In studying the board structure they were most interested in the composition and processes of the board as well as the structure and independence of key standing committees. In the audit area they focused on the processes and composition of the committees.

CGI rankings are rated from five (highest) to one (lowest). The top three countries in the CGI rankings were the United Kingdom (4.75), Canada (4.71) and Ireland (4.25). The Scandinavian countries had the lowest index values at slightly above one. In the report they ranked 18 industries and the banking industry ranked fifth last with an index value of 2.65 . The report highlights that there is a large variation of corporate governance factors across countries and industries.

Grunert et al. (2005) found that credit rating agencies take into account governance issues. This is forcing firms in countries that have not introduced similar legislation to SOX to adopt improved governance measures if they want to borrow in international markets. Roberts (2004) agrees saying firms are being forced to conform to international governance requirements to avoid bad ratings. This market pressure has resulted in banks in Southeast Asia and Japan adopting worldwide governance standards. Shinsei Bank in Japan is a good example of the changes these banks 
are undertaking. Shinsei has changed its board from 5 to 17 members with a range of backgrounds and countries.

Questions have been raised on the effectiveness of the new corporate Q gover irector is a better director contending that regulators an independent director is a better director con have lost sight of the role of the board which is independent oversight of management and corporate stewardship' ( $\mathrm{p}$. 3). They believe the idea of independent oversight is driving regulators who are insisting on independent directors as in Australia, Canada, the US and the United Kingdom. Wirectors as in Aust round little evidence to Westphal (2002) contends that past research has found litle evidence to suggest that independence leads to a better run company. Lawler and Finegold (2006) on the other hand suggest that external directors brin diversity and experience and are a benefit for the governance of a firm.

There have been a number of studies on specific governance attributes. Anere have (2004) found that board independence, size and a fully in(200) found that board indepton dependent audit committee had positive benefits when it came to creditors and loans. Bebchuk et al. (2005) examine the way directors are elected and this has an influence on firm value, staggering the election of directors reduce reduced vale. Bron an import(1) ant bearing on performance and Dahya and McConnell (2005) looked at boards with more independent directors and established they made better decisions as reflected in share price changes. Mak and Kusnadi (2002) disdecisions a $\mathrm{c}$ hoards have a positive relationship with firm value Studies prior to SOX by Jensen (1993), Mehran (1995), Yermack (1996), Klien (1998), and Vafeas (1999) on board characteristics, found composition, number of board meetings, committees, structure/size of the board, number of outside directors, plus the compensation of the external dire required under SOX or equivalent legislation and therefore these factor are no longer able to differentiate performance as before. It should be noted Leblanc and Gillies (2003) suggest there has been little learned about what is effective corporate governance. They believe it is board process in the is effective con done in this area.

\section{METHODOLOGY}

In this study we examine the corporate governance characteristics of the world's top 100 banks. The term bank in this study is used generically to refer to the entire operations of the reporting entity as disclosed in their consolidated annual report, not just their banking operations. The ranking of the top 100 banks was obtained from Forbes.com 2005 listing of the world's top 2000 companies. Appendix A contains a list of the banks, country of origin and the value of total assets. Reviewing the Federal Reserve's December 2005 report of foreign banks operating in the United States, 62 percent of non-US banks in the survey have operations in the United States at a branch or subsidiary level and this requires a number of the non-US banks to comply with the Sarbanes-Oxley Act as well as their own home country regulations. The requirement for foreign companies to comply with SOX came into force for financial year statements filed after 15 April 2005. This helps to explain why a large number of the non-US banks included sections in their annual report on how they were moving to be compliant with SOX although there is little evidence that what they are doing is anything more than the minimum possible.

The information used here on corporate governance and financial figures was extracted from each bank's annual report and proxy statement for 2004 obtained from the bank's web-site. In compiling the data it was found that the information reported by banks in their annual reports differed leading to some problems in obtaining information. For example the disclosure of external director compensation, number of board meetings, or years of service for each director was sometimes not reported.

The information obtained on the governance characteristics of the board of directors consisted of: the number of board members, the number of internal directors, independence of the chairperson, the number of board meetings per year the average number of years a director served on the board and the compensation paid to external directors. For the activities of the board, information gathered included existence of an audit committee, compensation committee, risk committee, and the independence of the audit and compensation committee. The annual report was reviewed to see if there were sections detailing the board's view on corporate governance and risk setting for the bank.

In the second part of the study the governance characteristics are converted into an index where regression tests are carried out to establish if there is significance in the differences in performance, risk measures and governance characteristics. Table 9.1 sets out the governance characteristics and the index score allocated to each variable. A value of one indicates that the bank complied with the requirement and zero that they did not. For example the governance characteristic that the board has an audit committee was given an index value of one. If the bank did not have an audit the or information was not provided the index value is zero. As a result of reporting differences between countries it was difficult to obtain the number of board meetings per year, compensation of external board 
Table 9.1 Board Characteristics - allocation of governance index values

\begin{tabular}{|c|c|c|}
\hline Actual values & \multicolumn{2}{|l|}{ Regression values } \\
\hline $\begin{array}{l}\text { Number of directors } \\
\text { Number of internal directors }\end{array}$ & \multicolumn{2}{|c|}{$\begin{array}{l}\text { Number of directors from annual report } \\
\text { Percentage of internal directors to all } \\
\text { directors from annual report }\end{array}$} \\
\hline Index numbers only & Index value of 1 & Index value of 0 \\
\hline $\begin{array}{l}\text { Chairman of the board } \\
\text { Number of board meetings } \\
\text { Average years on the board } \\
\text { Compensation external directors } \\
\text { Corporate governance statement } \\
\text { Risk statement } \\
\text { Board audit committee } \\
\text { Audit committee composition } \\
\text { Board compensation committee } \\
\text { Board compensation committee } \\
\text { Board risk committee }\end{array}$ & $\begin{array}{l}\text { Independent } \\
\text { Information provided } \\
\text { Information provided } \\
\text { Information provided } \\
\text { Statement provided } \\
\text { Statement provided } \\
\text { Committee established } \\
\text { All independent } \\
\text { Committee established } \\
\text { All independent } \\
\text { Committee established }\end{array}$ & $\begin{array}{l}\text { Non-Independent } \\
\text { No information } \\
\text { No information } \\
\text { No information } \\
\text { No statement } \\
\text { No statement } \\
\text { No committee } \\
\text { Not all independent } \\
\text { No committee } \\
\text { Not all independent } \\
\text { No committee }\end{array}$ \\
\hline
\end{tabular}

members and number of years of board service. Therefore in the first regression test these variables have an index value of one if this information was provided or zero if not.

Consolidated balance sheet information gathered was aimed at determining the level of loans to assets and basic risk. Information included total assets, loans and advances to customers, shareholders' funds, profit for the year and as a measure of risk; BIS capital percentage, equity to assets (equity capital ratio) and provision for loan losses to loans. The performance measures used in the analysis was return on assets and return on equity.

Analysis of the data was conducted in two parts. The first part was to establish an average for all of the 100 banks in the survey. This was to enable comparison analysis between banks, countries and regions. The second part of the study was directed towards a series of regression tests to evaluate if there were significant relationships between the governance variables to performance and risk. Before performing the regression analysis a study of correlations between the corporate governance variables was carried out. Appendix B sets out all the governance variables and the initial correlation matrix.

Appendix B shows a high degree of correlation between some of the governance variables, for example, board risk statement and the existence of a board risk committee. The evaluation of the correlations was systematically run through several stages to evaluate each high correlation to establish which variable should be removed for the regression tests. Once a variable was removed the process was repeated to logically remove highly correlated variables. In the first review there was a high correlation with the average years a director had served on the board, the number of board meetings plus the compensation of external directors. The removal of the two variables average years on the board and number of board meetings was made on the basis that banks that reported these items usually reported all three. As each variable was assigned a value of one or zero and the majority of banks had all three there was high correlation amongst the variables.

The second review revealed a high correlation between the audit committee and the compensation committee. Ninety-three percent of banks reported they had an audit committee and 89 percent had a compensation committee. With almost all banks having an audit committee it was believed that this characteristic did not contribute to the analysis and thus the audit committee was deleted. The third review of correlations showed high correlation between all external directors on both the audit committee and compensation committee. Most banks that reported these committees tended to comply with the SOX requirement for the audit committee but not always for the compensation committee. The removal of the audit committee comprised of all internal members was considered less likely to influence the regression tests.

The fourth review showed a high correlation with compensation of external directors and the compensation committee consisting of all external directors. The data on director compensation was poor and an index number was assigned for this variable with one for providing the information and zero if they did not. The majority of banks that reported the compensation of external directors also had external members on their compensation committee and the compensation of directors was seen as not adding to the analysis and therefore deleted.

The final review revealed a high correlation with the compensation committee consisting of all external members and the board risk committee. It was more unlikely that a bank had a compensation committee with all outside directors rather than a risk committee. When this variable was retained and the risk committee removed there was still a high level of correlation in the variables. Therefore the variable compensation committee consisting of all external members was removed and the risk committee retained. This resulted in six governance variables listed in Table 9.2 with their coefficients for the regression analysis in part two. 
Table 9.2 Final correlations of governance variables

\begin{tabular}{|c|c|c|c|c|c|c|}
\hline & $\begin{array}{l}\text { Number } \\
\text { of } \\
\text { directors }\end{array}$ & $\begin{array}{l}\text { Percentage } \\
\text { of internal } \\
\text { directors }\end{array}$ & $\begin{array}{l}\text { Independent } \\
\text { chairman }\end{array}$ & $\begin{array}{l}\text { Compensation } \\
\text { committee all } \\
\text { external } \\
\text { directors }\end{array}$ & $\begin{array}{l}\text { Governance } \\
\text { statement }\end{array}$ & $\begin{array}{c}\text { Risk } \\
\text { statement }\end{array}$ \\
\hline $\begin{array}{l}\text { No. of } \\
\text { directors }\end{array}$ & 1 & & & & & \\
\hline $\begin{array}{l}\text { No. of } \\
\text { internal } \\
\text { directors }\end{array}$ & -0.2557 & 1 & & & & \\
\hline $\begin{array}{l}\text { Independent } \\
\text { chairman }\end{array}$ & 0.1315 & -0.2357 & 1 & & & \\
\hline Risk commit. & -0.0749 & 0.0071 & -0.0737 & 1 & & \\
\hline $\begin{array}{l}\text { Corporate } \\
\text { governance } \\
\text { statement }\end{array}$ & 0.1980 & -0.0326 & -0.1275 & 0.1887 & & \\
\hline Risk stat. & 0.0833 & 0.1234 & 0.0513 & 0.2860 & 0.1689 & 1 \\
\hline
\end{tabular}

\section{RESULTS OF THE STUDY - COMPARISON TO THE AVERAGE BANK}

This section reports the overall summary results of the survey. The world's top 100 banks come from 28 countries. Refer to Appendix A for the list of banks. The US dominates with 26 banks and the next largest countries are Japan and the United Kingdom with eight each. Twelve countries had just one bank, Appendix $C$ contains a list of the countries represented in the survey and the number of banks. In compiling the data from the banks' annual reports it was observed that there are a number of differences in how the top banks are governed from director numbers, committee structures, number of internal directors and independence of the chairperson. Table 9.3, Panel A provides a summary of the average bank plus maximum and minimum values for each item across the sample. Table 9.3, Panel B shows percentage compliance with board governance characteristics. The average bank in the survey will have 14 directors and 25 percent will be internal. Banks on average hold ten board meetings a year and the directors have served almost eight years on the board. The average bank will have a board statement on corporate governance, an audit, compensation, and risk committees.

Ninety-nine percent of the banks reported a positive return on assets, the average return on assets is 0.96 percent and return on shareholder funds is 14.68 percent. The external directors' remuneration was not reported by
Table 9.3 The 'average' bank

Panel A: Figures for the average bank plus maximum and minimum values across the survey

\begin{tabular}{|c|c|c|c|}
\hline & \multirow{2}{*}{$\begin{array}{c}\text { Average } \\
\text { bank }\end{array}$} & \multicolumn{2}{|c|}{ Entire sample } \\
\hline & & Highest & Lowest \\
\hline \multicolumn{4}{|l|}{ Board characteristics } \\
\hline Number of directors & 14.6 & 29 & 5 \\
\hline Number of internal directors & 3.7 & 17 & 0 \\
\hline Number of board meetings & 10.2 & 33 & 4 \\
\hline Average years on the board & 7.7 & 22.4 & 1.1 \\
\hline \multicolumn{4}{|l|}{ Balance sheet statistics } \\
\hline Return on assets (\%) & 0.96 & 3.01 & -0.23 \\
\hline Return on equity (\%) & 14.68 & 32.39 & -8.43 \\
\hline Bank total assets US billion & $\$ 281.9$ & 1481.1 & 20.76 \\
\hline Percentage loans to assets & 56.73 & 96.1 & 4.9 \\
\hline \multicolumn{4}{|l|}{ Percentage provisions for } \\
\hline loan losses to loans & 1.97 & 9.13 & 0.3 \\
\hline Percentage equity to assets & 6.6 & 17.8 & 2.3 \\
\hline \multicolumn{4}{|l|}{ Percentage BIS risk capital } \\
\hline to risk assets & 12.6 & 36.0 & 9.5 \\
\hline
\end{tabular}

\section{Governance characteristics}

$(\%)$

Independent chairman of the board

Board statement on corporate governance

Board statement on risk direction for bank

Board audit committee

Audit committee all independent directors

Board compensation committee

Compensation committee all independent directors

Board risk committee

33 percent of the banks. In relation to US banks the calculation of external director remuneration was an estimate based on their proxy statements and the previous years' board and committee activities.

The definition of the banking industry is broad and the 'banks' in the study are large complex financial organizations (LCFO) with the reporting entity involved in many different financial activities. An interesting statistic from the information is the traditional role of banking 'loans and advances to customers' have reduced in significance of balance sheet proportions. 
The average value of loans and advances to customers is 56 percent of total assets. The reason for this lower figure could be due to mergers and acquisitions over recent years where commercial banks have merged to become financial service firms.

All the organizations in the survey have been identified as being in the banking industry by Forbes. However some banks are really financial service firms. For example State Street of the US has only 5 percent of assets as loans. Other banks with very small percentage of loans to assets are Mellon Financial 18 percent, Natexis Banques Populaire and BNP Paribus with 29 percent each. In contrast Washington Mutual of the US made specific mention that it did not consider itself a bank but rather a holding company that owned a bank. Interestingly Washington's percentage of loans to assets at 67 percent is higher than the survey average of 56 percent.

In compiling the data from the annual reports the majority of the World's top 100 banks are LCFOs with operations spanning several countries and they offer a broad range of financial services. For these banks to be successful and be in this listing it is reasonable to assume that they must have good corporate governance procedures.

The review of countries and the regions of Europe and Southeast Asia to the average bank revealed some variation in board composition and committee structure. Nonetheless their overall performance and balance sheet composition was not significantly different from the average bank. Overall Australian, Canadian and Southeast Asian banks are very similar. The Japanese and French banks have some of the most notable differences. Table 9.4 lists the summary for countries where there were five or more banks and the regions of Europe and Southeast Asia. Each of the major differences in governance characteristics are discussed below.

\section{Board of Directors}

Many studies have indicated that board size is seen as being important in good corporate governance. The average bank board has 14.6 directors with 3.7 ( 25 percent) being internal members. Not all banks reported remuneration for their non-executive directors therefore there was no meaningful data to analyse. The governance code in the United Kingdom suggests independent directors should not serve for more than ten years and the chairperson of the board should be external. This study revealed the average number of years' service that directors have served on a bank board is approximately seven and half. The US banks typically had the longest serving directors with an average of ten years. In assembling the

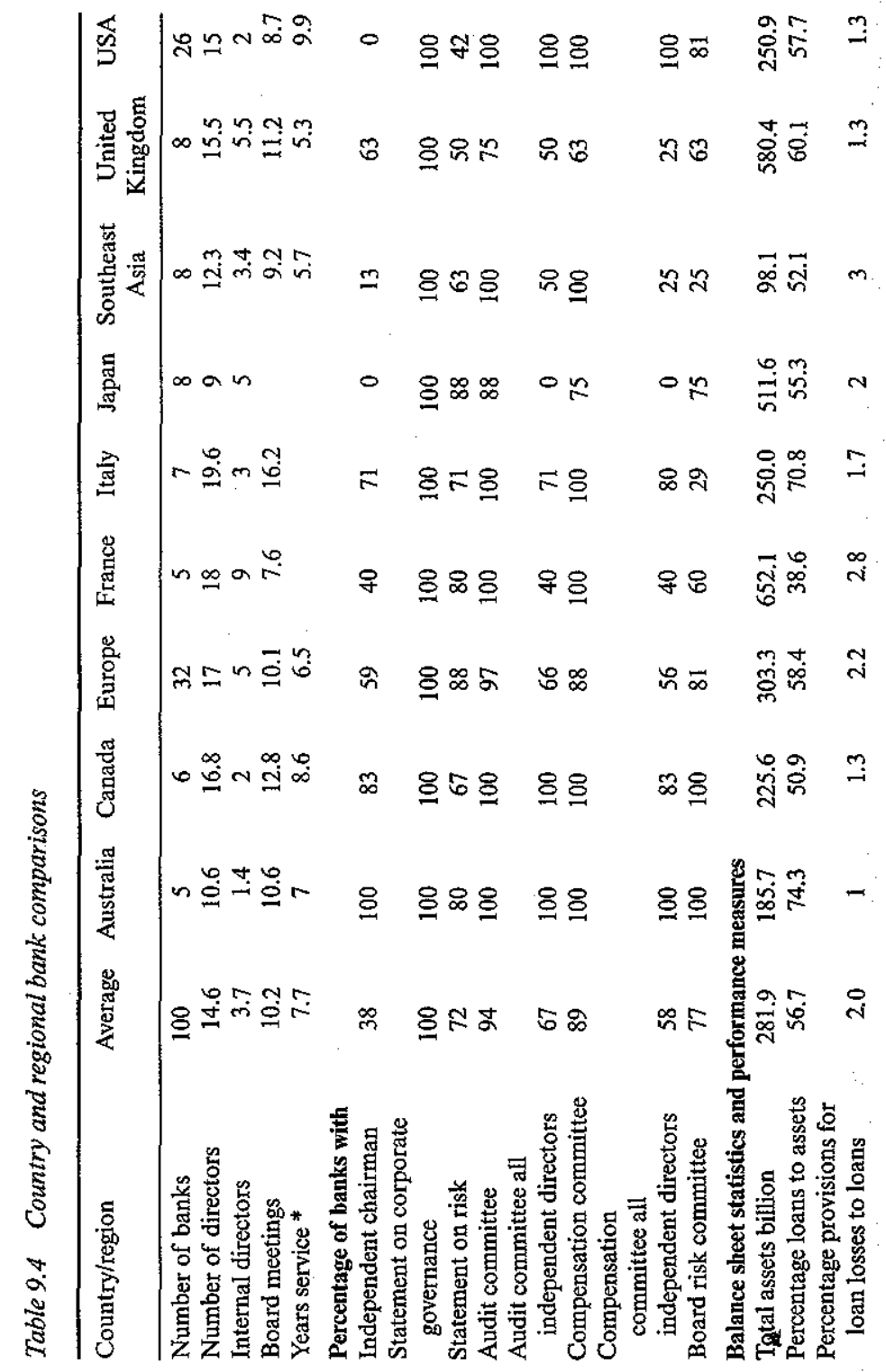

193 


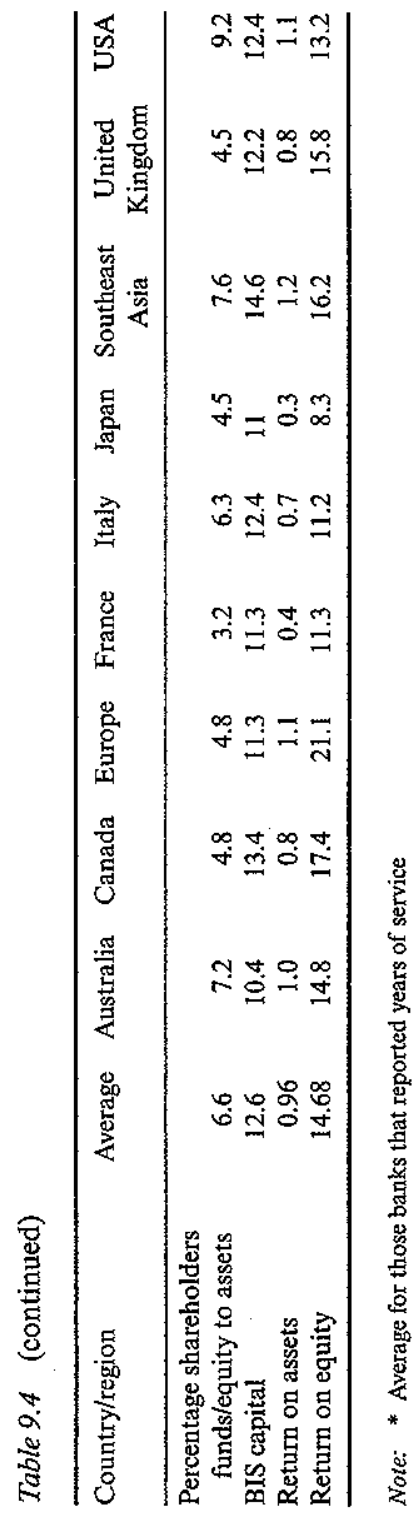

194 data it was observed the longest-serving external board member had been on one bank's board for 47 years. Only 38 percent of the banks have an independent chairperson and it was noted that none of the US or Japanese banks had this characteristic.

The Japanese banks were clearly different in their board structure. The Japanese bank board was small with an average of nine directors and the majority internal. They did not provide detailed information on board committees and membership. The smallest board was found in Japan with five directors and they are all internal Citibank the world's largest bank in 2005, had 20 directors, with five internal including the chairperson.

The Italian banks had the highest number of board members averaging 19.6 and the French had 50 percent internal directors the second highest in the study. In the case of the French banks many of the internal directors are staff elected representatives.

The US banks had the lowest number of board meetings per year at 8.7 compared to the average of 10.2 . The Italian banks had almost one-and-ahalf times more board meetings than all other banks at 16.2 meetings in the year. Monte Dei Paschi bank of Italy had 33 meetings in the year, the most of any bank. Several banks reported only four board meetings in the year but this did not seem to cause significant deviation from the average bank performance.

\section{Board Committee Structures}

All banks reported on their corporate governance practices however only 72 percent reported a board policy on risk setting and 77 percent of banks have a risk committee. In an industry where risk management is very important and forms part of the new Basel II capital adequacy requirements this seems a low compliance rate. Eighty-nine percent of banks had a compensation committee and the composition of this committee varied with 56 percent having all external directors. All banks other than the Japanese banks had an audit committee but only 67 percent of the banks had all independent members. The Japanese banks have an audit board instead of an audit committee.

The French banks had the lowest compliance with audit and compensation committees having all external board members. One possible explanation for this is that the French banks have a large number of elected staff representatives on their boards and these elected staff members are treated as being equivalent to external directors. Italian banks and the banks in Southeast Asia had low compliance with board risk committees, only 30 percent having a risk committee. 
Equity to Assets and Capital Adequacy

All banks reported healthy Bank for International Settlements capital adequacy ratios to risk assets, the average for the 100 banks is 12.58 percent compared to a minimum requirement of eight. In contrast the average percentage of equity to assets was merely 6.6 percent almost half the BIS figure. It should be noted that the BIS ratio compares risk assets taking into account the counterparty's credit risk and many banks have substantial non-bank lending activities including insurance and in some G10 countries insurance assets do not count in the calculation. In addition non-equity items can be included in the capital component in calculating the ratio such as long term subordinated debt.

The 'banks' in this study are large complex financial organizations and the calculation of the balance sheet equity to total asset ratio for some banks appears low. In reviewing the banks' equity to assets levels it poses a question regarding how banks with low levels of equity will adjust to the new capital adequacy rules required under Basel II. The BIS consultative document Overview of the new Basel Accord, released in January 2001 indicated that the new accord would apply not just to the banking group. They said the new accord would apply on a 'consolidated basis only at the highest level' (p. 11). Many of the banks indicated in their annual report that they were moving to adopt the new Basel II capital risk framework.

Some examples of banks that have low equity to assets levels are Commerzbank of Germany with 2 percent equity to assets and a BIS capital ratio of 12.6 percent. Their loans to assets figure is 32 percent. Commerzbank reported risk assets of $\$ 189.4$ billion compared to total assets of $\$ 575.9$ billion (32.9 percent risk assets to actual assets). Erste Bank of Austria has 2.4 percent equity to assets, a BIS ratio of 10.2 percent plus loans to assets of 52 percent. Erste bank's risk assets to total assets ratio is 46.8 percent. Crédit Agricole of France has equity to assets of 3.1 percent and a BIS ratio of 11.7 percent. Crédit Agricole's loans to assets are 62.4 percent and the percentage of risk assets to total assets are 52.5 percent. The above banks are just three of the 22 in the study with equity to assets levels below 4 percent. Current BIS capital rules require banks to have a minimum of 4 percent Tier 1 capital, however this 4 percent is calculated on risk assets not total assets and some G10 countries have an exemption for insurance activities.

The French banking industry has the lowest level of equity to assets with an average of 3.2 percent compared to the average bank's level of 6.6 percent. The French banks did report a healthy 11.2 percent BIS capital. French banks have relatively lower levels of loans to assets and hence lower risk assets plus larger insurance operations which could account for the difference. The banks in the US had the highest equity to assets level at 9.2 percent and an average 12.4 percent BIS capital.

\section{Loans to Assets and Provision for Loan Losses}

The average bank's loan to assets is 56.7 percent and the provision for loan losses to loans is 1.97 percent. The French banks have very low loans to assets of 38.6 percent, however they have a higher provision for loan losses to loans of 2.8 percent. The French banks were the second largest group of banks in terms of total assets. The French banks have average assets of \$US652.1 billion. The top seven US banks are the biggest banks with an average of $\$ 725$ billion. Australian banks had the highest loans to assets percentage at 74.3 but the lowest provision for loan losses at 1 percent.

\section{Return on Assets and Equity}

The average banks return on assets is 0.96 percent and return on equity 14.7 percent. The Japanese and French banks had the lowest return on assets a 0.3 percent and 0.4 percent respectively. The French banks have lower level of equity than the other banks and a larger reliance on debt therefore higher leverage. The Japanese banks are improving their performance after the well publicized problems of past loan losses. The return on equity was also low for the Japanese banks at 8.3 percent.

The French banks have a low return on equity of 11.3 percent compared to the average of 14.7 percent despite their higher gearing levels. The average return on equity for all European banks was high at 21 percent. The top bank in terms of return on equity is OTP Bank of Hungary at 32 percent. Akbank of Turkey had a return on assets of 2.9 percent, however their return on equity was close to average at 16 percent. The Standard Bank Group of South Africa earned 26 percent on equity and was the second highest to OTP with a healthy return on assets of 2.6 percent.

In looking at the board structure of OTP Bank it has a small board of six directors with 33 percent being internal and they did not report how many meetings they have a year. Also OTP bank did not report on board committees, corporate governance or risk statements. Akbank has a small board with nine directors and 55 percent are internal. Akbank did have statements on risk and corporate governance and a board committee for risk but not an audit or compensation committee and the board met 12 times a year. Standard Bank on the other hand has 19 directors with 19 percent internal. Standard Bank's directors had been on the board for an average of 7 years and they meet six times a year. These differences in governance characteristics have not impacted on their performance. 


\section{RESULTS OF THE REGRESSION ANALYSIS}

As described in the methodology section the key governance variables for the regression analysis are based around the characteristics of the board of directors namely, number of directors, percentage of inside directors, independent chairperson, and statements from the board on corporate governance, risk, and the existence of a risk committee. These were used to evaluate return on assets, return on equity, BIS capital adequacy, equity to assets, and provision for loan losses to loans. Table 9.5 provides the results of the regression analysis for each of the governance variables and performance characteristics for the 98 banks that provided information on the number of board members and identified who were internal.

Table 9.5 Regression results for six governance variables and 98 observations

Regression results of governance variables to bank performance and risk measures

\begin{tabular}{|c|c|c|c|c|c|}
\hline & $\begin{array}{l}\text { Return } \\
\text { on } \\
\text { assets }\end{array}$ & $\begin{array}{l}\text { Return } \\
\text { on } \\
\text { equity }\end{array}$ & $\begin{array}{l}\text { BIS } \\
\text { capital } \\
\text { ratio }\end{array}$ & $\begin{array}{l}\text { Equity } \\
\text { to } \\
\text { assets }\end{array}$ & $\begin{array}{l}\text { Provision } \\
\text { for loan } \\
\text { losses }\end{array}$ \\
\hline $\begin{array}{l}\text { Number of } \\
\text { directors }\end{array}$ & $\begin{array}{l}-0.0003 \\
(0.02522)^{*}\end{array}$ & $\begin{array}{c}-0.0020 \\
(0.15776)\end{array}$ & $\begin{array}{c}-0.1495 \\
(0.08502)\end{array}$ & $\begin{array}{c}-0.0005 \\
(0.43466)\end{array}$ & $\begin{array}{c}0.0417 \\
(0.22411)\end{array}$ \\
\hline $\begin{array}{l}\text { Percentage } \\
\text { of internal } \\
\text { directors }\end{array}$ & $\begin{array}{l}-0.0001 \\
(0.00001)^{* *}\end{array}$ & $\begin{array}{c}-0.0005 \\
(0.12225)\end{array}$ & $\begin{array}{c}-0.0094 \\
(0.61071)\end{array}$ & $\begin{array}{l}-0.0007 \\
(0.000005)^{* *}\end{array}$ & $\begin{array}{c}0.0117 \\
*(0.10893)\end{array}$ \\
\hline $\begin{array}{l}\text { Independent } \\
\text { chairman }\end{array}$ & $\begin{array}{l}-0.0035 \\
(0.00075)^{* *}\end{array}$ & $\begin{array}{c}0.0033 \\
(0.78940)\end{array}$ & $\begin{array}{c}-0.5799 \\
(0.44882)\end{array}$ & $\begin{array}{l}-0.0260 \\
(0.00001)^{* *}\end{array}$ & $\begin{array}{c}0.2993 \\
(0.92306)\end{array}$ \\
\hline $\begin{array}{l}\text { Risk } \\
\text { committee }\end{array}$ & $\begin{array}{c}-0.0001 \\
(0.91424)\end{array}$ & $\begin{array}{c}0.0091 \\
(0.53858)\end{array}$ & $\begin{array}{c}-0.8661 \\
(0.34065)\end{array}$ & $\begin{array}{c}-0.0062 \\
(0.35916)\end{array}$ & $\begin{array}{l}-1.0506 \\
(0.00433)^{* *}\end{array}$ \\
\hline $\begin{array}{l}\text { Board } \\
\text { governance } \\
\text { statement }\end{array}$ & $\begin{array}{l}-0.0211 \\
(0.00004)^{* *}\end{array}$ & $\begin{array}{l}-0.1750 \\
(0.00483)^{* *}\end{array}$ & $\begin{array}{c}3.1973 \\
(0.39325)\end{array}$ & $\begin{array}{c}-0.0327 \\
(0.23903)\end{array}$ & $\begin{array}{c}-0.7755 \\
(0.60168)\end{array}$ \\
\hline $\begin{array}{c}\text { Board risk } \\
\text { statement }\end{array}$ & $\begin{array}{c}-0.0002 \\
(0.82863)\end{array}$ & $\begin{array}{c}0.0085 \\
(0.54568)\end{array}$ & $\begin{array}{c}-0.1719 \\
(0.84201)\end{array}$ & $\begin{array}{c}-0.0085 \\
(0.18663)\end{array}$ & $\begin{array}{c}0.0922 \\
(0.78778)\end{array}$ \\
\hline Regression $R^{2}$ & 0.3637 & 0.1379 & 0.0521 & 0.3308 & 0.1365 \\
\hline $\begin{array}{l}\text { Significance } \\
\text { of } F \text { Statistic }\end{array}$ & $0.0000001^{* *}$ & $0.0321^{*}$ & 0.5477 & $0.000001^{* *}$ & $0.03387^{*}$ \\
\hline
\end{tabular}

Notes: The figures in parentheses are the $P$-values from the regression test and the figures above the bracketed figure is the coefficient.

** Indicates significance at the 1 percent confidence leve
The multiple regression analysis for return on assets and equity to assets had the most significant results at the 1 percent level. In both cases the significant governance characteristics at the 1 percent level was percentage of internal directors to directors and independent chairperson both with negative coefficients. Indicating that a smaller number of internal directors are favorable and an internal chairperson would improve bank performance and increase equity to asset levels. However the conclusion could be slightly biased in that all US banks have internal chairpersons and the highest levels of equity to assets. This results in a higher return on assets than other banks that have higher leverage. In interpreting the result of more external directors are important, it is argued that external directors bring a new perspective to the organization that improves performance.

The evaluation of the BIS capital adequacy was not statistically significant. The return on equity and provision for loan losses were only significant at the 5 percent confidence level. In the analysis of the return on equity the significant governance variable was a board statement on corporate governance which does not seem to be logical given that 99 percent of the banks had this statement. This could indicate that there is another variable that has not been identified in the study or from prior research that is important.

The significant governance variable in determining the provision for loan losses to loans was the existence of a risk committee which had a negative coefficient. This would seem to be at odds with the notion of loan loss provisioning. The interpretation could be that with a risk committee more detailed analysis is put into reviewing the loss provisions or the bank has better credit modeling ability and it could be possible that the provision for losses is a more accurate reflection of the potential losses compared to banks without such committees.

A second regression analysis was performed that included the numbers reported for board meetings in a year and the average years of service on the board rather than in the first regression analysis which included simply the index value of one or zero for these items. Changing these variables reduced the number of banks in the analysis to 68 and removed all the Brazilian, German and Italian banks from the analysis as well as reducing the numbers of Japanese and French banks. The inclusion of the variables as numbers increased the number of governance variables without correlation problems. Table 9.6 shows the results of this analysis. At the 1 percent significance level the performance measure return on assets was highly significant and measures of BIS capital adequacy, equity to assets, and provision for loan losses were all significant at the 1 percent level. Return on equity was significant at the 5 percent confidence level. The overall results of the regression improved with higher $R^{2}$ values and improved significance levels. 
Table 9.6 Regression results eight governance variables 68 observations Regression results for reported numbers of directors, percentage of internal directors to directors, average years of board service and number of meetings, compensation committee, compensation committee all independent board members, board statement on risk regressed to bank performance and risk measures.

\begin{tabular}{|c|c|c|c|c|c|}
\hline & $\begin{array}{l}\text { Return } \\
\text { on } \\
\text { assets }\end{array}$ & $\begin{array}{l}\text { Return } \\
\text { on } \\
\text { equity }\end{array}$ & $\begin{array}{l}\text { BIS } \\
\text { capital } \\
\text { ratio }\end{array}$ & $\begin{array}{l}\text { Equity } \\
\text { to } \\
\text { assets }\end{array}$ & $\begin{array}{l}\text { Provision } \\
\text { for loan } \\
\text { losses }\end{array}$ \\
\hline $\begin{array}{l}\text { Number of } \\
\text { directors }\end{array}$ & $\begin{array}{l}-0.0085 \\
(0.50645)\end{array}$ & $\begin{array}{c}-0.0821 \\
(0.60928)\end{array}$ & $\begin{array}{c}0.0096 \\
(0.88788)\end{array}$ & $\begin{array}{c}0.0005 \\
(0.50213)\end{array}$ & $\begin{array}{c}0.0511 \\
(0.22286)\end{array}$ \\
\hline $\begin{array}{l}\text { Percentage of } \\
\text { internal } \\
\text { directors }\end{array}$ & $\begin{array}{l}-0.0104 \\
(0.00657)^{* *}\end{array}$ & $\begin{array}{c}0.0436 \\
(0.34933)\end{array}$ & $\begin{array}{c}-0.0144 \\
(0.46721)\end{array}$ & $\begin{array}{l}-0.0008 \\
(0.00016)^{* *}\end{array}$ & $\begin{array}{l}-0.0151 \\
(0.21343)\end{array}$ \\
\hline $\begin{array}{l}\text { Independent } \\
\text { chairman }\end{array}$ & $\begin{array}{l}-0.3418 \\
(0.00101)^{* *}\end{array}$ & $\begin{array}{c}1.8710 \\
(0.13658)\end{array}$ & $\begin{array}{l}-0.9540 \\
(0.07613)\end{array}$ & $\begin{array}{l}-0.0285 \\
(0.0000)^{* *}\end{array}$ & $\begin{array}{l}-0.0851 \\
(0.79251)\end{array}$ \\
\hline $\begin{array}{l}\text { Average years } \\
\text { on the board }\end{array}$ & $\begin{array}{c}-0.0098 \\
(0.55763)\end{array}$ & $\begin{array}{l}-0.2745 \\
(0.19249)\end{array}$ & $\begin{array}{c}0.0698 \\
(0.43487)\end{array}$ & $\begin{array}{l}0.0005 \\
(0.59441)\end{array}$ & $\begin{array}{c}0.0105 \\
(0.84702)\end{array}$ \\
\hline $\begin{array}{l}\text { Number of } \\
\text { board } \\
\text { meetings } \\
\text { per year }\end{array}$ & $\begin{array}{c}-0.0164 \\
(0.21159)\end{array}$ & $\begin{array}{c}-0.1461 \\
(0.37457)\end{array}$ & $\begin{array}{c}-0.0162 \\
(0.81666)\end{array}$ & $\begin{array}{c}0.0002 \\
(0.80057)\end{array}$ & $\begin{array}{c}0.0451 \\
(0.29167)\end{array}$ \\
\hline $\begin{array}{l}\text { Compensation } \\
\text { committee }\end{array}$ & $\begin{array}{l}-2.0393 \\
(0.00000)^{* *}\end{array}$ & $\begin{array}{l}-2.7705 \\
(0.43199)\end{array}$ & $\begin{array}{l}-20.6174 \\
(0.00000)^{* *}\end{array}$ & $\begin{array}{l}-0.1177 \\
(0.00000)^{* *}\end{array}$ & $\begin{array}{l}-3.6195 \\
*(0.00019)^{* *}\end{array}$ \\
\hline $\begin{array}{l}\text { Compensation } \\
\text { committee all } \\
\text { independent } \\
\text { directors }\end{array}$ & $\begin{array}{l}0.3367 \\
(0.00706)^{* *}\end{array}$ & $\begin{array}{l}5.1252 \\
(0.00126)^{* *}\end{array}$ & $\begin{array}{l}-0.5342 \\
+(0.41085)\end{array}$ & $\begin{array}{c}0.0028 \\
(0.66819)\end{array}$ & $\begin{array}{c}-0.6315 \\
(0.11367)\end{array}$ \\
\hline $\begin{array}{c}\text { Board risk } \\
\text { statement }\end{array}$ & $\begin{array}{c}0.0381 \\
(0.71097)\end{array}$ & $\begin{array}{l}1.0675 \\
(0.40888)\end{array}$ & $\begin{array}{c}0.2140 \\
(0.69709)\end{array}$ & $\begin{array}{l}-0.0103 \\
(0.07151)\end{array}$ & $\begin{array}{l}-0.0862 \\
(0.79689)\end{array}$ \\
\hline Regression $R^{2}$ & 0.5942 & 0.2053 & 0.8055 & 0.7023 & 0.3378 \\
\hline $\begin{array}{l}\text { Significance } \\
\text { of } F \text { Statistic }\end{array}$ & $0.000000^{* *}$ & $0.02981^{*}$ & $0.00000^{* *}$ & $0.00000^{* *}$ & $0.0013^{* *}$ \\
\hline
\end{tabular}

Notes: The figures in parentheses are the $P$-value from the regression test and the figures Notes: The figures in parentheses are the $P$ abe the bracketed figure is the coefficient.
above

** Indicates significance at the 1 percent confidence level

* Indicates significance at the 5 percent confidence level

Changing the governance characteristics of average years of board service and number of board meetings per year from index values to service and no nignificant factors in their own right for the second regression analysis. The governance variable compensation committee was significant at the 1 percent level for all measures except return on equity. Interestingly the coefficient is negative for all regressions. In analyzing the result for return on assets does this mean that banks with compensation committees pay higher rewards to their senior executives?

To answer this question a review of the banks' annual reports in relation to the operation of the compensation committee was conducted and it was noted that these committees select a peer or aspirant group to compare their executives' salaries to. A large number of bank compensation committees stated that they wanted their executives to be remunerated at or near the top of the peer group. If each bank takes this approach it seems that salaries will always be increasing as the peer group remuneration levels are always increasing. Another factor is most banks list some of the world's top 20 banks in their peer group. The compensation committee reported that the setting of executive salaries had a flow on effect for the rest of the bank staff. Given the significance of this characteristic it would seem that compensation committees are increasing wage costs and reducing profits. Banks without such committees are possibly not taking as active a role in comparing remuneration arrangements for senior staff.

Gordon (2006) agrees with this finding. He reports:

in setting executive pay, compensation committees typically relied on the compensation consultant that also provided firm-wide compensation and human resources guidance. This consultant is hired by management and earns the largest part of its fee from the firm-wide assignment. Such a conflicted consultant is unlikely to make recommendations or offer viewpoints that senior management would find distressing. (p. 28)

The other governance variable that is significant at the 1 percent level is the percentage of internal directors with a negative coefficient. This variable was also significant in the first regression test and indicates lower levels of internal directors are important and seems logical as the independent board members bring an external perspective to the bank.

A third regression analysis was run on the number of board members only and this did not prove to be significant at the 1 percent level. It was noted that the sign for the coefficient was negative for all performance and risk measures indicating that small boards are better as found in past research. Brown and Caylor (2004) have suggested the optimal board size is between six and 15, however in this study we have not tried to evaluate the optimal size of the board.

Several other regression tests were evaluated including one on the total governance index value but this failed to produce a meaningful result. A 
Table 9.7 Regression results for eight governance variables and 68 observations

Regression results for reported numbers of directors, percentage of internal directors to directors, average years of board service and number of meetings in the governance variables to bank performance and risk measures.

\begin{tabular}{|c|c|c|c|c|c|}
\hline & $\begin{array}{l}\text { Return } \\
\text { on } \\
\text { assets }\end{array}$ & $\begin{array}{l}\text { Return } \\
\text { on } \\
\text { equity }\end{array}$ & $\begin{array}{c}\text { BIS } \\
\text { capital } \\
\text { ratio }\end{array}$ & $\begin{array}{l}\text { Equity } \\
\text { to } \\
\text { assets }\end{array}$ & $\begin{array}{c}\text { Provision } \\
\text { for loan } \\
\text { losses }\end{array}$ \\
\hline $\begin{array}{l}\text { Number of } \\
\text { directors }\end{array}$ & $\begin{array}{c}-0.0208 \\
(0.2248)\end{array}$ & $\begin{array}{c}-0.0218 \\
(0.89609)\end{array}$ & $\begin{array}{c}-0.1714 \\
(0.22058)\end{array}$ & $\begin{array}{l}-0.0006 \\
(0.53156)\end{array}$ & $\begin{array}{c}0.0104 \\
(0.82422)\end{array}$ \\
\hline $\begin{array}{l}\text { Percentage of } \\
\text { internal } \\
\text { directors }\end{array}$ & $\begin{array}{l}-0.0118 \\
(0.00742)^{* *}\end{array}$ & $\begin{array}{c}-0.0146 \\
(0.72950)\end{array}$ & $\begin{array}{c}0.0255 \\
(0.46833)\end{array}$ & $\begin{array}{l}-0.0008 \\
(0.00244)^{* *}\end{array}$ & $\begin{array}{c}-0.0017 \\
(0.88740)\end{array}$ \\
\hline $\begin{array}{l}\text { Independent } \\
\text { chairman }\end{array}$ & $\begin{array}{l}-0.3195 \\
(0.01640)^{*}\end{array}$ & $\begin{array}{l}2.7810 \\
(0.03346)^{*}\end{array}$ & $\begin{array}{c}-1.3488 \\
(0.20929)\end{array}$ & $\begin{array}{l}-0.0319 \\
(0.00008)^{* *}\end{array}$ & $\begin{array}{c}-0.2570 \\
(0.47548)\end{array}$ \\
\hline $\begin{array}{l}\text { Average years } \\
\text { on the board }\end{array}$ & $\begin{array}{l}-0.0066 \\
(0.67025)\end{array}$ & $\begin{array}{l}-0.1034 \\
(0.63031)\end{array}$ & $\begin{array}{c}-0.0201 \\
(0.91022)\end{array}$ & $\begin{array}{l}-0.0002 \\
(0.89275)\end{array}$ & $\begin{array}{l}-0.0247 \\
(0.68141)\end{array}$ \\
\hline $\begin{array}{l}\text { Number } \\
\text { of board } \\
\text { meetings } \\
\text { per year }\end{array}$ & $\begin{array}{c}0.0078 \\
(0.64435)\end{array}$ & $\begin{array}{c}-0.1507 \\
(0.36911)\end{array}$ & $\begin{array}{c}0.2666 \\
(0.05885)\end{array}$ & $\begin{array}{c}0.0016 \\
(0.09953)\end{array}$ & $\begin{array}{l}0.0991 \\
(0.03766)^{*}\end{array}$ \\
\hline Regression $R^{2}$ & 0.2139 & 0.0887 & 0.1119 & 0.3467 & 0.0781 \\
\hline $\begin{array}{l}\text { Significance of } \\
F \text { Statistic }\end{array}$ & $0.00927^{* *}$ & 0.3163 & 0.1846 & $0.00005^{* *}$ & 0.3962 \\
\hline \multicolumn{6}{|c|}{$\begin{array}{l}\text { Regression results of number of directors to performance } \\
\text { and risk measures }\end{array}$} \\
\hline Regression $R^{2}$ & 0.0469 & 0.0263 & 0.0266 & 0.0015 & 0.0102 \\
\hline $\begin{array}{l}\text { Significance of } \\
F \text { Statistic }\end{array}$ & 0.03216 & 0.1105 & 0.1089 & 0.7098 & 0.3248 \\
\hline Coefficient & -0.00027 & -0.00216 & -0.1275 & -0.00027 & 0.0329 \\
\hline
\end{tabular}

Notes: The figures in parentheses are the $P$-value from the regression test and the figures above the bracketed figure is the coefficient.

** indicates significance at the 1 percent confidence level

* indicates significance at the 5 percent confidence level

regression test using the numbers for board of directors, percentage of internal directors, number of years on the board, independent chairperson and number of board meetings per year failed to change the results of the first regressions tests and are shown in Table 9.7.

\section{CONCLUSIONS}

There have been a number of studies into corporate governance characteristics and firm performance. It has been observed that there is variation between researchers as to what variables are important. This study of the world's top 100 banks demonstrates that there are differences in corporate governance. However, it does not seem to make a significant difference in performance as measured by return on assets.

The comparison study of the various countries showed that the Japanese banks tend to have a small number of directors, which according to some researchers is a positive attribute but our study failed to find this characteristic significant. However the Japanese banks had the lowest return on assets and equity. In our tests it was found that the percentage of interna directors was significant at the $l$ percent confidence level. The lower the percentage of internal directors the better the return on assets and this is one of the major differences of the Japanese banks compared to the average bank as they have approximately 40 percent internal directors. This also explained the differences in the French and Italian banks' low return on assets.

The large percentage of internal directors assisted in the explanation of low equity to asset levels for the Japanese, French and banks in the United Kingdom. There was no governance variable that satisfactorily explained the return on equity and BIS capital.

Overall the effect of the new governance legislation seems to be that banks have added a number of committees to meet the requirements of legislation such as SOX but all this has done is remove these variables as predictors of performance that previous researchers had found important. This study examined 13 governance characteristics and found the independence of the board may become the most important characteristic in determining bank performance. The results of the study did not suggest that the chairperson of the board has to be independent as some legisla tion calls for.

In summary the key findings are that banks that have fewer internal directors may perform better than banks that have higher percentage of internal directors. The move by boards to establish audit and compensation committees are no longer a differentiator in performance.

This study highlighted some areas for further investigation, for example, large banks with low equity to total asset levels. The new Basel II capital adequacy rules may cause some banks to review their operations as 'banks' and split their operation into commercial banks and financial service firms due to the requirements of operational risk and other risk measures.of the new accord. 


\section{REFERENCES}

Andersen, R., S. Mansi and D. Reeb (2004), 'Board characteristics, accounting report integrity, and the cost of debt', Journal of Accounting and Economics, 37, $315-42$.

Basel Committee on Banking Supervision (2001); 'Overview of the new Basel accord' Bank for International Settlements consultative document, Basel, Switzerland.

Bebchuk, L. A. A. Cohen and A. Ferrell (2004), 'What matters in corporate governance?' Harvard Law School, discussion paper no. 491, September.

Brown, L. and M. Caylor (2004), 'Corporate governance and firm performance', working paper, Georgia State University.

Chidambaran, N. K., D. Palia and Y. Zheng (2006), 'Does better corporate governance "cause" better firm performance", working paper, accessed at SSRN http://ssrn.com/abstract $=891556$.

Core, J. E., W. R. Guay and T. O. Rusticus (2006), 'Does weak governance cause weak stock returns? An examination of firm operating performance and investors' expectations', Journal of Finance, 61, 655-87.

Dahya J. and J. J. McConnell (2005), 'Outside directors and corporate board decisions', Journal of Corporate Finance, 11, 37-60.

Federal Reserve (2005) report of foreign banks operating in the United States December, accessed at www.federalreserve.gov/releases/iba/default.htm.

Forbes.com (2004), The World's 2000 Largest Public Companies, accessed August 2005 at www.forbes.com/lists.

FTSE (2005), FTSE ISS Corporate Governance Rating and Index Series Measuring the Impact of Corporate Governance on Global Portfolios, New York: FTSE Institutional Shareholder Services, April.

Gompers, P. J. Ishii and A. Metrick (2003), 'Corporate governance and equity prices', The Quarterly Journal of Economics, 118, 107-55.

Gordon, J. N. (2006) 'Independent directors and stock market prices: the new corporate governance paradigm', European Corporate Governance Institute working paper no. 74/2006, accessed at http://ssrn.com/abstract $=928100$.

Grunert, Worden and M. Weber (2005), 'The role of non-financial factors in international credit ratings', Journal of Banking and Finance, 29, 509-31.

international cres) 'The modern industrial revolution, exit and the failure of internal control systems', Journal of Finance, 48, 831-80.

Klein, April (1998), 'Firm performance and board committee structure', Journal of Law and Economics, $41,275-303$.

Lawler III, E. E. and D. Finegold (2006), 'Who's in the boardroom and does it matter: the impact of having non-director executives attend board meetings', Organizational Dynamics, 35, 106-9.

Leblanc $R$ and J Gillies (2003) 'The coming revolution in corporate governance', Ivey Business Journal, $68,1-11$.

Mak Y T and Y Kusnadi (2002) 'Size really matters: further evidence on the negative relationship between board size and firm value', working paper National University of Singapore.

Mehran, Hamid (1995) 'Executive compensation structure, ownership, and firm performance', Journal of Financial Economics, 38, 163-84.

peror (2004) 'American companies climb to the top of the global corporate Roberts, D. (2004), 'Aminacial Times, 7 September 1 .
Vafeas, N. (1999), 'Board meeting frequency and firm performance', Journal of Financial Economics, 53, 113-42.

Westphal, J. D. (2002), 'Second thoughts on board independence: why do so many demand board independence when it does so little good?' The Corporate Board, 23, 6-10.

Yermack, D. (1996), 'Higher market valuation of companies with a small board of directors', Journal of Financial Economics, 40, 185-221. 


\section{APPENDIX 9A: TOP 100 BANKS}

\begin{tabular}{|c|c|c|c|c|c|c|c|}
\hline Rank & Bank & Country & Assets & Rank & Bank & Country & Assets \\
\hline 1 & Citigroup & United States & 1484.10 & 51 & Bank of Ireland & Ireland & 130.91 \\
\hline 2 & Bank of America & United States & 1110.46 & 52 & Standard Bank Group & South Africa & 80.73 \\
\hline 3 & HSBC Group & United Kingdom & 1031.29 & 53 & CIC Group & France & 195.75 \\
\hline 4 & Royal Bank of Scotland & United Kingdom & 1119.90 & 54 & DnB NOR & Norway & 105.46 \\
\hline 5 & JPMorgan Chase & United States & 1138.47 & 55 & PNC Financial Services & United States & 77.3 \\
\hline 6 & BNP Paribas & France & 1228.03 & 56 & Golden West Financial & United States & 106.89 \\
\hline 7 & Barclays & United Kingdom & 1002.09 & 57 & State Street & United States & 94.04 \\
\hline 8 & Wells Fargo & United States & 427.85 & 58 & Banco Popular Español & Spain & 84.83 \\
\hline 9 & HBOS & United Kingdom & 729.31 & 59 & KeyCorp & United States & 90.74 \\
\hline 10 & Wachovia & United States & 411.14 & 60 & Monte Dei Paschi & Italy & 153.71 \\
\hline 11 & Mizuho Financial & Japan & 1306.60 & 61 & Erste Bank & Austria & 161.27 \\
\hline 12 & Société Générale Group & France & 678.36 & 62 & Firstrand & South Africa & 68.87 \\
\hline 13 & Banco Santander & Spain & 435.75 & 63 & DBS Group & Singapore & 107.51 \\
\hline 14 & Lloyds TSB Group & United Kingdom & 450.02 & 64 & BCP-Bco Com Portugujs & Portugal & 97.26 \\
\hline 15 & Mitsubishi Tokyo Finl & Japan & 1014.56 & 65 & Sumitomo Trust \& Banking & Japan & 145.82 \\
\hline 16 & ABN-Amro Holding & Netherlands & 825.81 & 66 & Regions Financial & United States & 84.08 \\
\hline 17 & Sumitomo Mitsui Financial & Japan & 962.87 & 67 & Mellon Financial & United States & 37.12 \\
\hline 18 & BBVA-Banco Bilbao Vizcaya & Spain & 422.08 & 68 & Sberbank of Russia & Russia & 50.53 \\
\hline 19 & Crédit Agricole & France & 987.79 & 69 & BOC Hong Kong & Hong Kong/China & 98.22 \\
\hline 20 & Royal Bank of Canada & Canada & 351.74 & 70 & Natexis Banques Populaire & France & 170.95 \\
\hline 21 & Natl Australia Bank & Australia & 298.36 & 71 & Türkiye Is Bankasi & Turkey & 30.76 \\
\hline 22 & UniCredito Italiano & Italy & 299.22 & 73 & Northern Rock & United Kingdom & 82.13 \\
\hline 23 & US Bancorp & United States & 195.10 & 74 & Alliance \& Leicester & United Kingdom & 86.47 \\
\hline 24 & Washington Mutual & United States & 307.92 & 75 & United Overseas Bank & Singapore & 82.65 \\
\hline
\end{tabular}

\begin{tabular}{|c|c|c|c|c|c|c|}
\hline Dexia & Belgium & 439.58 & 76 & National Bank of Greece & Greece & 67.56 \\
\hline Nordea Bank & Sweden & 330.03 & 77 & M\&T Bank & United States & 52.94 \\
\hline Banca Intesa & Italy & 324.11 & 78 & Shinhan Financial & South Korea & 116.73 \\
\hline Bank of Nova Scotia & Canada & 228.37 & 79 & Mitsui Trust & Japan & 119.49 \\
\hline Commonwealth Bank Group & Australia & 213.59 & 80 & St George Bank & Australia & 50.85 \\
\hline ANZ Banking & Australia & 187.69 & 81 & Akbank & Turkey & 20.76 \\
\hline Toronto-Dominion Bank & Canada & 255.15 & 82 & Comerica & United States & 51.77 \\
\hline Danske Bank Group & Denmark & 340.07 & 83 & Resona Holdings & Japan & 381.18 \\
\hline Sanpaolo IMI & Italy & 252.79 & 84 & National Bank of Canada & Canada & 72.65 \\
\hline Westpac Banking Group & Australia & 177.76 & 85 & Kookmin Bank & South Korea & 156.23 \\
\hline Canadian Imperial Bank & Canada & 227.85 & 86 & OTP Bank & Hungary & 23.04 \\
\hline National City & United States & 139.28 & 87 & AmSouth Bancorp & United States & 49.69 \\
\hline Bank of Montreal & Canada & 217.73 & 88 & Eurohypo & Germany & 283.65 \\
\hline Banco Bradesco Group & Brazil & 69.63 & 89 & Unibanco Group & Brazil & 29.88 \\
\hline Standard Chartered Group & United Kingdom & 141.69 & 90 & Malayan Banking & Malaysia & 46.92 \\
\hline SunTrust Banks & United States & 127.79 & 91 & BPVN Group & Italy & 60.9 \\
\hline Bank of New York & United States & 94.53 & 92 & Marshall \& Ilsley & United States & 38.98 \\
\hline Fifth Third Bancorp & United States & 98.29 & 93 & Northern Trust & United States & 45.28 \\
\hline Svenska Handelsbanken & Sweden & 203.02 & 94 & North Fork Bancorp & United States & 60.67 \\
\hline Allied Irish Banks & Ireland & 138.46 & 95 & Capitalia & Italy & 159.55 \\
\hline Commerzbank & Germany & 575.94 & 96 & Banche Popolari Unite & Italy & 78.92 \\
\hline BB\&T & United States & 100.51 & 97 & Banco de Sabadell & Spain & 57.39 \\
\hline Banco do Brasil & Brazil & 89.99 & 98 & Oversea-Chinese Banking & Singapore & 49.73 \\
\hline SEB-Skand Enskilda Bank & Sweden & 239.48 & 99 & Sovereign Bancorp & United States & 54.47 \\
\hline FöreningsSparbanken & Sweden & 153.57 & 100 & Popular & United States & 44.4 \\
\hline State Bank of India Group & India & 127 & 102 & Bank of Yokohama & Japan & 101.42 \\
\hline
\end{tabular}




\section{APPENDIX 9B: CORRELATIONS OF GOVERNANCE VARIABLES}

\begin{tabular}{|c|c|c|c|c|c|c|c|c|c|c|c|c|}
\hline & \multirow{2}{*}{$\begin{array}{l}\text { Number } \\
\text { of } \\
\text { Directors }\end{array}$} & \multirow{2}{*}{$\begin{array}{l}\text { Percentage } \\
\text { of internal } \\
\text { Directors } \\
\text { on board }\end{array}$} & \multirow[t]{2}{*}{$\begin{array}{l}\text { Independent } \\
\text { Chairman }\end{array}$} & \multirow{2}{*}{$\begin{array}{l}\text { Average } \\
\text { Years } \\
\text { on } \\
\text { Board }\end{array}$} & \multirow{2}{*}{$\begin{array}{l}\text { Number } \\
\text { of } \\
\text { Board } \\
\text { Meetings }\end{array}$} & \multirow{2}{*}{$\begin{array}{c}\text { Audit } \\
\text { Committee }\end{array}$} & \multirow{2}{*}{$\begin{array}{l}\text { Audit } \\
\text { all } \\
\text { external } \\
\text { members }\end{array}$} & \multirow[t]{2}{*}{$\begin{array}{c}\text { Risk } \\
\text { Committee }\end{array}$} & \multirow{2}{*}{$\begin{array}{l}\text { Corporate } \\
\text { Governance } \\
\text { Statement }\end{array}$} & \multirow{2}{*}{$\begin{array}{c}\text { Board } \\
\text { Risk } \\
\text { Statement }\end{array}$} & \multicolumn{2}{|c|}{$\begin{array}{l}\text { Compensation } \\
\text { committee }\end{array}$} \\
\hline & & & & & & & & & & & Committee & $\begin{array}{c}\text { All } \\
\text { external } \\
\text { directors }\end{array}$ \\
\hline $\begin{array}{l}\text { Number of } \\
\text { Directors } \\
\text { Number of } \\
\text { internal }\end{array}$ & 1.0000 & & & & & & & & & & & \\
\hline $\begin{array}{l}\text { Directors } \\
\text { Independent }\end{array}$ & -0.2557 & 1.0000 & & & & & & & & & & \\
\hline $\begin{array}{l}\text { Chairman } \\
\text { Years on }\end{array}$ & 0.1315 & -0.2358 & 1.0000 & & & & & & & & & \\
\hline $\begin{array}{l}\text { Board } \\
\text { Compensation }\end{array}$ & -0.0371 & -0.3225 & -0.1384 & 1.0000 & & & & & & & & \\
\hline $\begin{array}{l}\text { external } \\
\text { directors } \\
\text { Number of } \\
\text { Board }\end{array}$ & 0.0415 & -0.3530 & -0.0127 & 0.6133 & 1.0000 & & & & & & & \\
\hline $\begin{array}{l}\text { Meetings } \\
\text { Audit }\end{array}$ & 0.2212 & -0.1638 & -0.1010 & 0.0707 & 0.1127 & 1.0000 & & & & & & \\
\hline $\begin{array}{l}\text { Committee } \\
\text { Audit all }\end{array}$ & 0.2235 & -0.6492 & 0.1811 & 0.3864 & 0.3633 & 0.3409 & 1.0000 & & & & & \\
\hline $\begin{array}{l}\text { external } \\
\text { Compensation }\end{array}$ & -0.0749 & 0.0071 & -0.0738 & 0.2860 & 0.1523 & 0.3198 & 0.1599 & 1.0000 & & & & \\
\hline $\begin{array}{l}\text { Committee } \\
\text { Compensation }\end{array}$ & 0.1980 & -0.0327 & -0.1276 & -0.0610 & 0.2005 & 0.4379 & 0.1493 & 0.1887 & 1.0000 & & & \\
\hline $\begin{array}{l}\text { all external } \\
\text { Risk }\end{array}$ & 0.0833 & 0.1235 & 0.0513 & -0.0470 & 0.0971 & 0.1758 & -0.0609 & 0.2860 & 0.1690 & 1.0000 & & \\
\hline $\begin{array}{c}\text { Committee } \\
\text { Governance }\end{array}$ & 0.2147 & -0.2193 & -0.0777 & 0.3319 & 0.1639 & 0.6878 & 0.2781 & 0.3842 & 0.3012 & 0.2556 & 1.0000 & \\
\hline Statement & 0.1904 & -0.5717 & 0.1070 & 0.4415 & 0.3522 & 0.2792 & 0.6405 & 0.1005 & 0.1223 & -0.0288 & 0.4059 & 1.0000 \\
\hline Risk Statement & 0.0415 & -0.3530 & -0.0127 & 0.6133 & 1.0000 & 0.1127 & 0.3633 & 0.1523 & 0.2005 & 0.0971 & 0.1639 & 0.3522 \\
\hline
\end{tabular}

